\title{
SPHK2 wt Allele
}

National Cancer Institute

\section{Source}

National Cancer Institute. SPHK2 wt Allele. NCI Thesaurus. Code C128471.

Human SPHK2 wild-type allele is located in the vicinity of 19q13.33 and is approximately $11 \mathrm{~kb}$ in length. This allele, which encodes sphingosine kinase 2 protein, plays a role in lipid phosphorylation. 